\title{
Pelatihan International English Language Testing System (IELTS) Bagi Alumni Fresh Graduate Fakultas Teknik Gowa Universitas Hasanuddin
}

\author{
Fauzan Djamaluddin ${ }^{1} *$, Ilyas Renreng ${ }^{1}$, Onny Sutresman ${ }^{1}$ \\ Departemen Teknik Mesin, Fakultas Teknik Universitas Hasanuddin ${ }^{1}$ \\ fauzanman_77@yahoo.com*
}

\begin{abstract}
Abstrak
IELTS (International English Language Testing System) merupakan tes kecakapan Bahasa Inggris terstandar yang menjadi prasyarat untuk melanjutkan studi atau berkerja. Workshop ini bertujuan untuk membantu pihak fakultas teknik dalam upayanya unutuk meningkatkan kemampuan penguasaan bahasa Inggris bagi sarjana baru yang dirancang dan diorientasikan pada penguasaan bahasa Inggris berekuivalensi IELTS. Mengingat kondisi masih dalam bencana pandemic covid-19 maka semua kegitan dilakukan secara daring (on-line). Kegiatan ini kerjasama antara pihak depatemen teknik mesin dan BRITON selaku mitra. Selain itu, jadwal kegiatan ini berlangsung selama 3 hari, dari tanggal 28 hingga 30 Agustus 2020 dari jam 10 pagi sampai jam 4 sore. Peserta terdaftar pelatihan dan ujian berjumlah 20 (dua puluh orang) yang terdiri dari mahasiswa semester akhir dan sarjana baru fakultas teknik Universitas Hasanuddin. Secara keseluruhan kegiatan diharapkan berlangsung dengan lancar dan dengan antusias mengikuti proses Workshop dari awal hingga akhir. Keberhasilan program ini juga terlihat dari tercapainya indikator keberhasilan yang telah ditetapkan yaitu jumlah peserta yang hadir pada workshop dan pre-tes sesuai yang diharapkan yaitu melebihi $80 \%$.dan $50 \%$
\end{abstract}

Kata Kunci: Workshop; IELTS; Fakultas Teknik; Departemen Teknik Mesin; Pre Tes.

\begin{abstract}
IELTS (International English Language Testing System) is a standardized English proficiency test which is a prerequisite for continuing study or work This workshop aims to assist the engineering faculty in its efforts to improve the mastery of English for new graduates which is designed and oriented towards mastering English with IELTS equivalents. All the activities had done by on line becauses of covid-19 pandemic. This activities collaborate between Mechanical Engineering Department and BRITON as parnert. This activity lasted for 3 days, from 28 to 30 August 2020. There were 20 (twenty) participants consisting of new graduates from the Hasanuddin University engineering faculty. Overall, the activities are expected to run smoothly and enthusiastically follow the Workshop process from beginning to end. The success of this program can also be seen from the achievement of predetermined success indicators, namely the number of participants who attended the workshop and the pre-test as expected, which exceeded $80 \%$ and $50 \%$.
\end{abstract}

Keywords: Workshop; IELTS; Fakulty Of Engineering; Departmen Of Mechanical Engineering; Pre Test.

\section{Pendahuluan}

Persaingan global dalam berbagai bidang menuntut penguasaan kompetensi skill dan akademik yang memadai dan dapat dipertanggungjawabkan. Dalam dunia pendidikan nasional Indonesia berbagai bentuk upaya telah dilakukan sebagai persiapan untuk menghadapi persaingan global ini, terutama untuk menghasilkan lulusan yang mampu bersaing, baik untuk melanjutkan ke jenjang pendidikan yang lebih tinggi maupun dalam dunia kerja. Selain upaya-upaya yang dilakukan pemerintah melalui Departemen Pendidikan Nasional, berbagai upaya juga dilakukan secara mandiri oleh berbagai sekolah, baik dasar, menengah maupun pendidikan tinggi, antara lain dengan mencanangkan mutu pendidikan dan pengelolaan bertaraf internasional. Komitmen ini sebenarnya memiliki implikasi dan konsekuensi yang tidak kecil bagi sekolah/lembaga pendidikan yang yang bersangkutan. Banyak hal yang harus dilakukan, mulai dari pembenahan fasilitas, perbaikan kurikulum, pengembangan materi ajar, perbaikan sistem pengelolaan administrasi maupun akademik, dan 
yang paling mendasar, peningkatan kemampuan sumber daya manusia yang akan menjalankan dan mendukung komitmen tersebut.

Dalam upaya peningkatan kualitas sumber daya manusia di dunia pendidikan, penguasaan bahasa asing, terutama bahasa Inggris, merupakan suatu hal yang sangat penting. Hal ini didasari atas berbagai pertimbangan. Dengan memberlakukan standar mutu internasional, sebuah sekolah telah berkomitmen untuk memasuki sebuah ranah pengelolaan yang tidak lagi berpatokan pada standar dan tuntutan mutu lokal sehingga memerlukan sumber daya manusia yang mampu memahami seluk beluk informasi yang yang dibutuhkan dalam ranah sehingga dapat mendukung kinerja mereka dalam mewujudkan komitmen lembaga. Penyampaian materi secara dwi-bahasa merupakan tuntutan wajib bagi sekolah-sekolah bertaraf internasional. Hal ini tentu saja mustahil dilaksanakan jika para guru/pengajar tidak memiliki kompetensi berbahasa Inggris. Oleh karena itu, upaya untuk meningkatkan penguasaan bahasa Inggris bagi guru dan karyawan merupakan bukti keseriusan sebuah sekolah untuk mewujudkan komitmen menuju sekolah bertaraf internasional. Seperti halnya universitas lainnya menuju world class university berbenah diri secara terus-menerus dalam rangka meningkatkan mutu pengajaran dan pengelolaan sebagai upaya untuk menuju sekolah bertaraf internasional. Sudah menjadi komitmen sekolah tersebut untuk membekali siswanya kemampuan berbahasa Inggris sehingga mereka diharapkan memiliki daya saing yang tinggi untuk melanjutkan ke jenjang pendidikan berikutnya. Komitmen ini dibuktikan dengan pengajaran dwi-bahasa pada beberapa mata pelajaran non-bahasa Inggris. Untuk mndukung dan mencapai tujuan di atas, departemen mesin berupaya untuk juga meningkatkan kemampuan penguasaan bahasa Inggris, terutama bagi sarjana baru. Workshop Bahasa Inggris berekualensi IELTS merupakan salah satu upaya yang dapt dilakukan untuk meningkatkan kemampuan penguasaan bahasa Inggris bagi guru dan karyawan. Materi Workshop yang diberikan mencakup skil-skil dasar yang sangat berguna untuk menunjang kemampuan berkomunikasi baik lisan maupun tertulis. Materi tersebut adalah Structure, Reading, dan Listening. Structure merupakan dasar bagi penguasaan skil dasar yang lain karena dengan penguasaan struktur bahasa yang baik, kemampuan dalam bidang bahasa yang lain secara signifikan dapat ditingkatkan. Materi-materi structure yang diberikan antara lain Tenses, Verb Pattern, Nouns dan Noun Phrase, Adjective dan Adverb, Passive, Conjuction dan Preposition. Reading diberikan dengan tujuan agar peserta dapat memiliki kemampuan untuk memahami teks-teks bahasa Inggris yang beragam, baik dari segi tema maupun tingkat kesulitan teks.materi-materi yang terkait dengan reading antara lain Vocabulary, Main Ideas, Reference, dan Message. Dengan cakupan materi seperti itu peserta diharapkan dapat memiliki kemampuan memahami teks dari segi isi maupun kosa kata yang digunakan.Kemampuan Listening merupakan hal yang sangat penting dalam pembelajaran bahasa Inggris sehingga peserta diharapkan dapat memiliki kemampuan memahami teks-teks yang bersifat audio (suara) yang merupakan bagian komunikasi sehari-hari yang sangat dominan.Untuk itulah program ini dirancang sebagai upaya untuk memberikan sumbangan yang bermanfaat bagi masyarakat, terutama bagi dunia pendidikan. Workshop Bahasa Inggris berekuivalensi IELTS ini diharapkan dapat membantu para guru dan karyawan untuk memotivasi diri dan mengoptimalkan potensi yang mereka miliki dalam bahasa Inggris sehinga mereka dapat memberikan sumbangan yang berarti bagi sekolah, dan terlebih lagi bagi pengembangan karir mereka sendiri.

\section{Latar Belakang Teori}

Bahasa Inggris berekuivalensi IELTS merupakan salah satu aspek dalam Workshop bahasa Inggris yang menekankan pada peningkatan penguasaan skil dasar seperti Structure, Reading, dan Listening. Masing-masing bidang memiliki metode pembelajaran dan oprientasi yang 
berbeda. Structure menekankan pada pemahaman hal-hal yang berhubungan dengan tata bahasa seperti jenis-jenis kata, tipe-tipe kalimat, frasa, hubungan antar elemen kalimat, tenses dan sebagainya. Pengetahuan tentang struktur bahasa sangat dibutuhkan tidak hanya bagi pembelajar bahasa Inggris untuk tujuan akademik, namun juga bagi mereka yang mempelajari bahasa Inggris untuk tujuan yang lebih praktis. Hal ini antara lain karena struktur/gramar bersifat spesifik dan sering berbeda antara satu bahasa dengan bahasa lain. Bahasa Inggris memiliki struktur/grammar yang sangat berbeda dengan bahasa Indonesia. Perbedaan tata bahasa ini juga tentu saja berpengaruh pada bentuk-bentuk ujaran, baik lisan maupun tertulis. Oleh karena itu, pengetahuan struktur ini akan berpengaruh pada kemampuan lain seperti listening, reading, dan speaking.

Dalam reading (terutama eading comphrehensian) orientasi utamanya adalah pemahaman teks (bacaan). Hal yang paling mendasar dalam memahami sebuah teks berbahasa asing adalah penguasaan kosa kata. Dengan penguasaan kosa kata yang kaya, seorang pembaca akan lebih mudah memahami isi atau pesan yang terkandung dalam sebuah teks. Dalam reading kosa kata dapat dibedakan menjadi dua, kosa kata umum dan kosa kata khusus atau teknis. Kosa kata umum adalah kata-kata yang secara umum digunakan dalam berbagai tingkat komunikas dan tidak secara khusus terkait dengan topik tertentu. Sedangkan kosa kata khusus atau teknis adalah kata-kata atau istilah-istilah yang secara eksklusif terkait dengan topik-topik atau bidang tertentu. Hal lain yang sangat dalam reading adalah pemahaman tentang topik bacaan dan pesan yang ingin disampaikan oleh penulis. Kedua hal ini membutuhkan telaah bacaan yang lebih mendalam dan latihan yang cukup memadai dan beragam karena tiap-tipa teks biasanya memiliki topik dan pesan yang berbeda dan spesifik. Kemampuan Listening lebih bersifat praktis sehingga praktek metrupakan metode yang paling tepat untuk menguasai kedua skill ini. Listening bertujuan untuk memahami ujaran lisan, baik dalam komunikasi langsung maupun termediasi (sarana audio). Listening memiliki kesulitan tersendiri, terutama menyangkut perbedaan pola pelafalan (pronounciation) antara bahasa Inggris dengan bahasa Indonesia. Sebuah kalimat yang dituliskan sangat mungkin terdengar berbeda ketika diucapkan, apalagi jika diucapkan oleh native speaker. Banyak kata dalam bahasa Inggris yang memiliki pelafalan yang sama atau hampir sama walaupun ejaannya berbeda, atau kata yang ejaannya sama atau hampir sama namun dilafalkan berbeda. Kesulitan yang lain dalam listening adalah menyangkut idiom dan ungkapan. Sebuah idiom biasanya memiliki bentuk khusus yang sering kali sangat berbeda dengan kata pembentuknya..

\section{Metode Pelaksanaan}

Kegiatan ini berbentuk Workshop dan pre-tes yang berlangsung selama 3 hari. Materi Workshop dirancang berdasarkan permintaan pihak kampus. Tim hanya sekedar menyesuaikan materi yang menjadi kebutuhan pihak kampus. Kegiatan dilaksanakan selama tiga hari, dari tanggal 28 - 30 Agustus 2020. adapun rincian jadwal pelaksanaan adalah sebagai berikut:

Tabel 1. Jadwal pelaksanaan

\begin{tabular}{lcc}
\hline Hari/Tanggal & Jam & Materi \\
\hline Jumat 28/08/2020 & $10.00-15.30$ & Workshop Daring oleh BRITON \\
Sabtu 29/08/2020 & $10.00-15.30$ & Pre - Test 1 Daring oleh BRITON
\end{tabular}


Tim pelaksana kegiatan ini terdiri dari dosen departemen teknik mesin. Untuk mengetahui kemampuan awal para peserta maka dilaksanakan pre-test dengan materi test Bahasa Inggris berekuivalensi IELTS setelah dilakukan Workshop dibagi dalam skil dasar yaitu, Listening, Structure and Written Expression, dan Reading Comprehension. Untuk materi Listening dan Reading diberikan dalam tiga sesi Workshop, sedangkan materi Structure \& Written Expression diberikan dalam empat sesi pertemuan. Tiap sesi dilaksanakan selama 90 menit dengan perimbangan teori dan praktek dalam bentuk mengerjakan soal latihan. Sebelum workshop, informasi kegiatan ini disebar di media social seperti WAG dan Facebook seperti terlihat pada gambar 1 dimulai pada bulan Juni - Agustus 2020. Peserta workshop dan Pre-tes ini terdiri atas 20 orang.

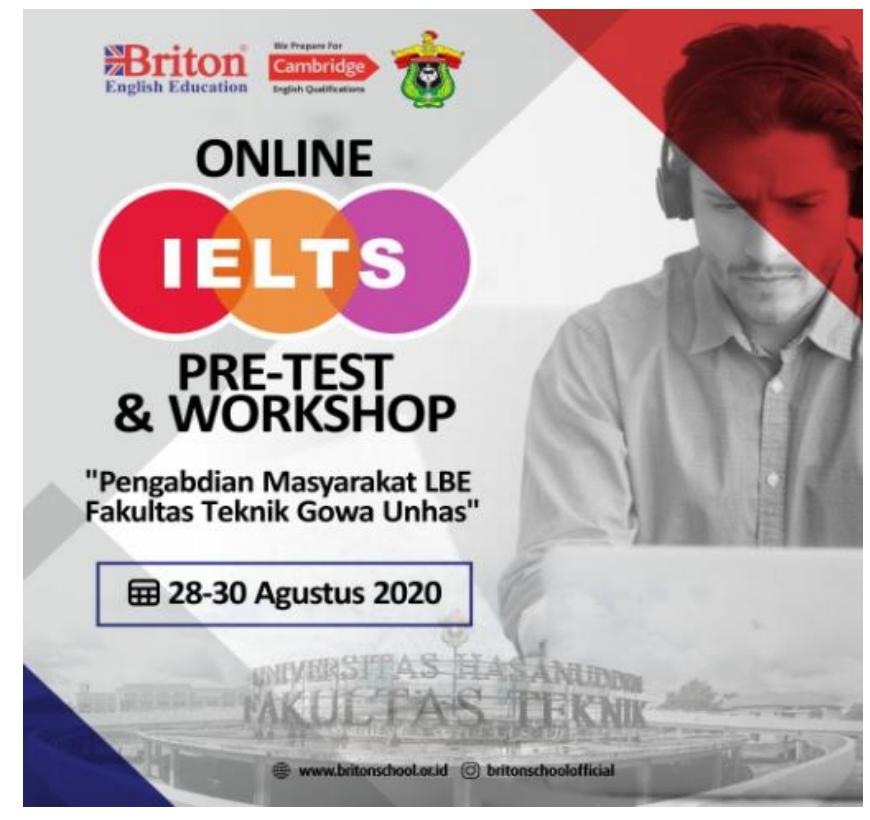

Gambar 1. Brosur workshop dan pre test

Daftar Peserta workshop dan pre-tes

1. Agim Chrismastori

2. Amrang

3. Elvys Salurapa

4. Hans Hezron

5. Jordi Marianus

6. Fadil Achsan

7. Muhammad Fathir Nugraditama

8. Annisa Fildza Shaffira

9. M ardi Isragusra

10. A nur Izzania Aulania

11. Halik Rifki dg Taha

12. Nur Ainun Annisa Mutmainnah

13. Annisa Fildza Shaffira

14. Elvys Salurapa

15. M Ardi Isragusra

16. Muhammad Fathir Nugraditama 
17. A Nur Izzania Aulania

18. Jordi Marianus

19. Rizal Amil Aulia Kasman

20. Setyawati Dewi Mulya

Kemudian pada tanggal 28 Agustus dilakukan workshop IELTS dari pihak Briton dengan materi Listening, Reading, Writing dan Speaking untuk IELTS. Sebelumnya dibuka oleh ketua pelaksana (Gambar 2 dan 3). Hasil tesnya akan dikirimkan oleh pihak mitra dalam 1 bulan ke depan.

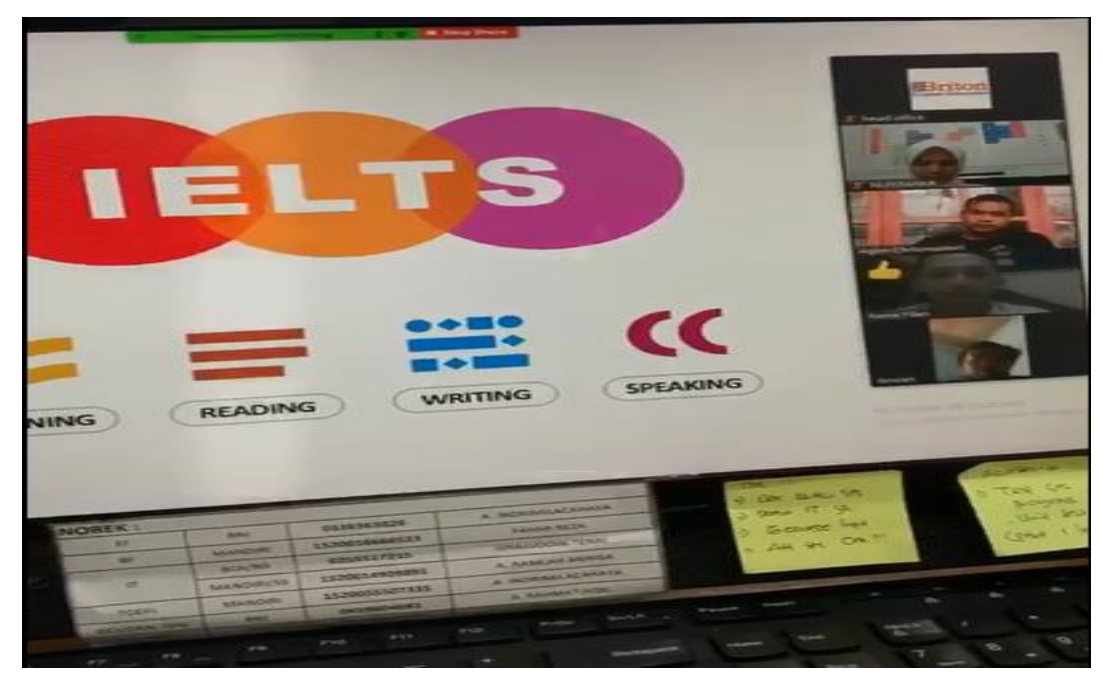

Gambar 2. Workshop secara daring

Pada tanggal 29 -30 dilakukan Pre-Test yang dipantau langsung oleh pihak BRITON

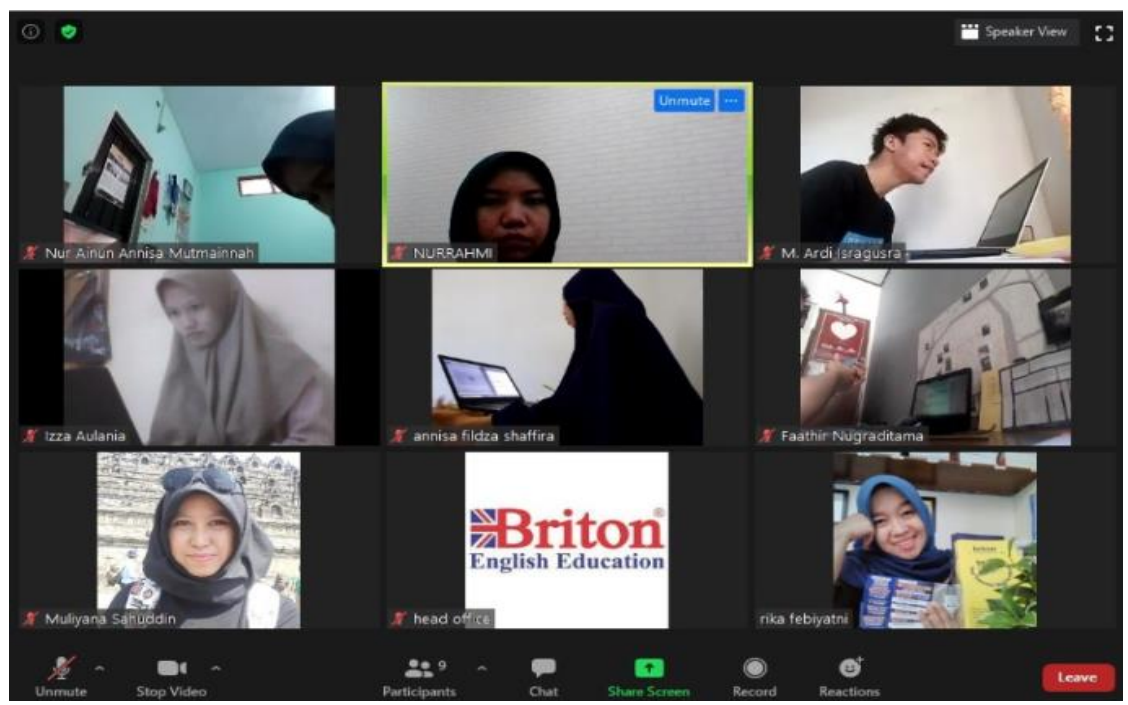




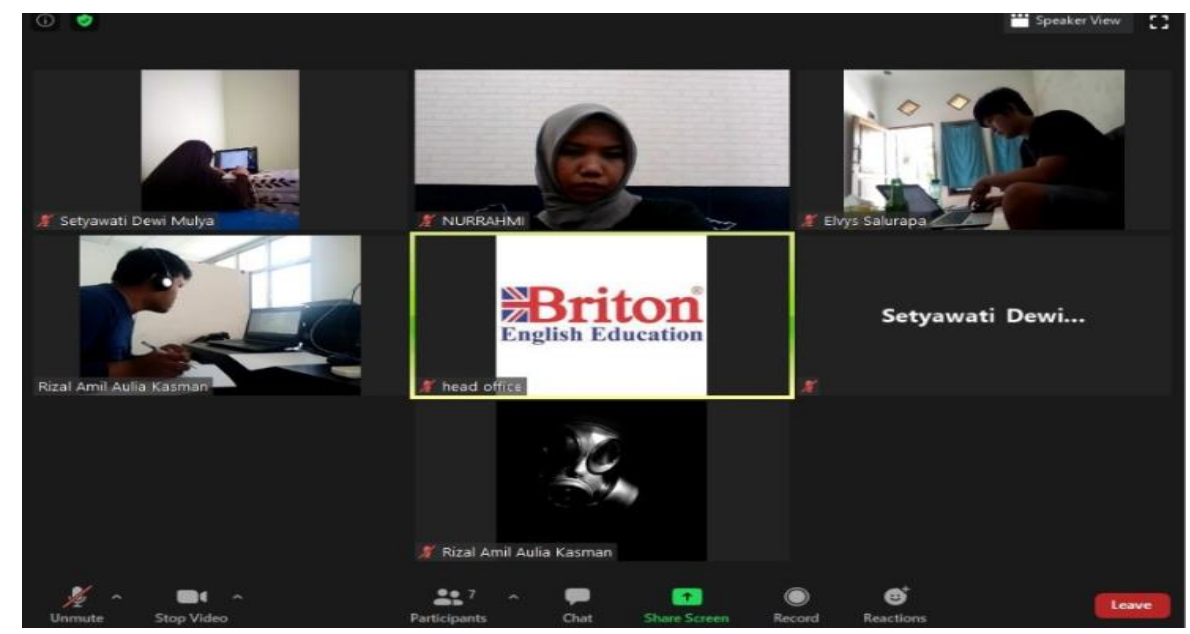

Gambar 3. Pelaksanaan Pre Test 1 dan 2

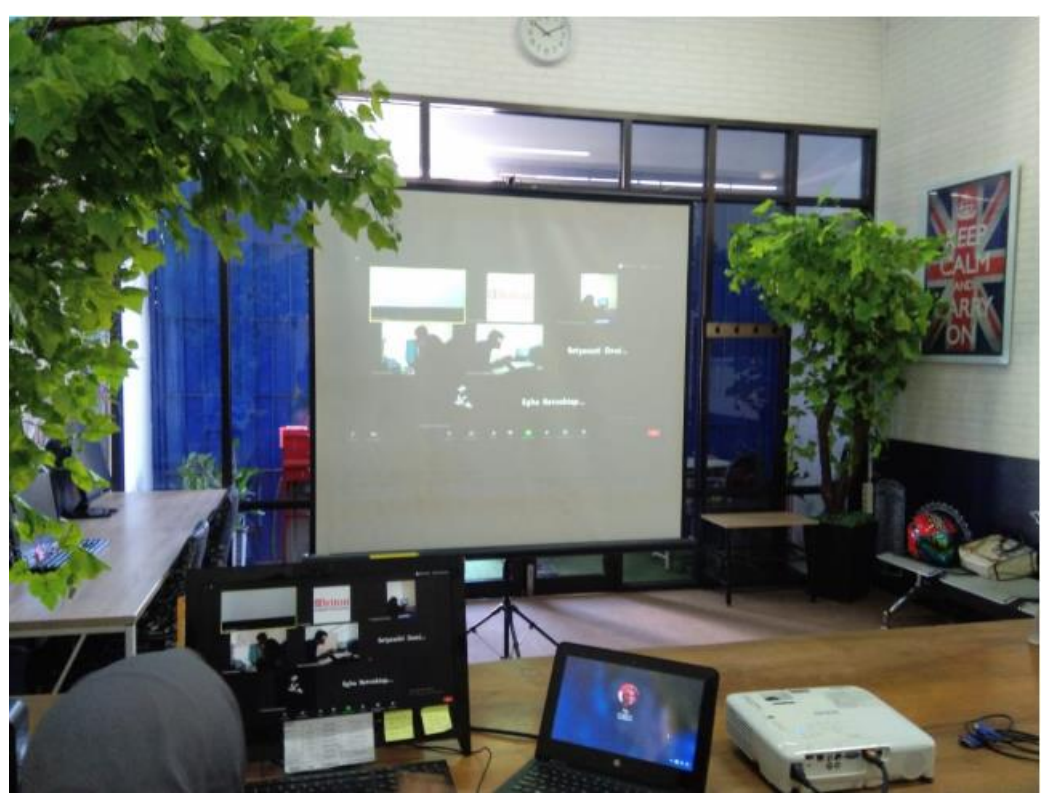

Gambar 4. Proses pemantauan pelaksanaan Pre Test dari pihak Briton

\section{Hasil dan Diskusi}

Setelah Workshop berlangsung maka sarjana baru Fakultas Teknik Universitas Hasanuddin memiliki kemampuan penguasaan Bahasa Inggris yang memadai, terutama dalam keterampilan dasar yang dibagikan dalam workshop. Workshop yang optimal dicapai dengan indikator keberhasilan sebagai berikut:

1. Jumlah peserta Workshop dan kehadiran tidak kurang dari 80 persen

2. Jumlah peserta pre-test tidak kurang dari 50 persen dari target jumlah peserta

\section{Kesimpulan}

Kegiatan ini merupakan program pengabdian masyarakat LBE di Departemen Teknik Mesin, Fakultas Teknik Unhas untuk meningkatkan soft skill khususnya Bahasa Inggris dari alumni fresh graduate. Aktifitas berupa workshop atau Workshop dan Pre Test yang dilakukan secara daring oleh mitra yaitu BRITON. Kedepannya Workshop juga untuk tingkat fakultas untuk peserta lebih banyak. 


\section{Ucapan Terima Kasih}

Ucapan terima kasih kepada pihak BRITON selaku mitra kegiatan workshop dan pre-test IELTS yang telah membantu dalam terlaksananya kegiatan pengabdian masyarakat ini. Ucapan terima kasih pula disampaikan kepada Fakultas Teknik Universitas Hasanuddin yang telah memberikan bantuan dana dalam pelaksanaan pengabdian masyarakat LBE. Demikian pula pada pihak peserta yaitu alumni sarjana baru dan mahasiswa tingkat akhir atas kerjasama sehingga kegiatan ini dapat berlangsung sukses sesuai yang diharapkan oleh panitia pelaksana.

\section{Daftar Pustaka}

Cambridge (2011). IELTS 8. The United Kingdom: Cambridge University Press.

Fauzan, Nafizah Zarei, Muhammad Bagheri (2018) Tips Dan Strategi IELTS, Reach The Peak PT. Andi Indonesia. 